\title{
A qualitative investigation of lay perspectives of diagnosis and self-management strategies employed by people with progressive Multiple Sclerosis.
}

\begin{tabular}{|c|l|}
\hline Journal: & Health \\
\hline Manuscript ID & Health-16-0044.R2 \\
\hline Manuscript Type: & Original Manuscript \\
\hline Keywords: & $\begin{array}{l}\text { Chronic illness and disability, Patient-physician relationship, Quality of life, } \\
\text { Experiencing illness and narratives, Gender and health }\end{array}$ \\
\hline & $\begin{array}{l}\text { This paper explores how people with progressive Multiple Sclerosis (MS) } \\
\text { give meaning to their experiences. It builds upon the self-management } \\
\text { literature, which has captured the tension between the desire for retaining } \\
\text { normalcy and the increasing burden of self-management associated with } \\
\text { chronic disease progression. This repeat interview study is empirically } \\
\text { grounded in twenty eight interviews with fourteen people with progressive } \\
\text { MS. We identified gender differences in diagnosis-seeking which impacted } \\
\text { upon subsequent sense-making. Male respondents found a diagnosis of MS } \\
\text { difficult to come to terms with, and an enduring sense of loss or anger } \\
\text { could inhibit further sense-making. A diagnosis of MS was more difficult to } \\
\text { obtain for women respondents, and any sense of certainty that diagnosis } \\
\text { provided framed their subsequent sense-making strategies. The complex } \\
\text { sequelae of MS require that self-management strategies are both } \\
\text { contextual and timely; although even the most accomplished self- } \\
\text { managers can lose their sense of self with neurodegeneration. Disease } \\
\text { progression can be associated with suicidal ideation, suggesting the need } \\
\text { for greater dialogue to ensure that people with MS are adequately } \\
\text { supported to fulfil their quality of life at all stages of neurodegeneration. } \\
\text { These lay perspectives emphasise the articulation of affect rather than the } \\
\text { rendering of a medical diagnosis, although diagnosis may provide a degree } \\
\text { of certainty in the short term. The ethos of self-management ensures } \\
\text { people attempt to retain their sense of 'normality' and existent social roles } \\
\text { for as long as possible, but this ethos can negate both ones' ability to self- } \\
\text { manage and the management of self. }\end{array}$ \\
\hline mbstract \\
\hline
\end{tabular}

\section{SCHOLARONE ${ }^{m}$ \\ Manuscripts}




\title{
A qualitative investigation of lay perspectives of diagnosis and self-
} management strategies employed by people with progressive Multiple

\section{Sclerosis.}

\begin{abstract}
This paper explores how people with progressive Multiple Sclerosis (MS) give meaning to their experiences. It builds upon the self-management literature, which has captured the tension between the desire for retaining normalcy and the increasing burden of self-management associated with chronic disease progression. This repeat interview study is empirically grounded in twenty eight interviews with fourteen people with progressive MS. We identified gender differences in diagnosisseeking which impacted upon subsequent sense-making. Male respondents found a diagnosis of MS difficult to come to terms with, and an enduring sense of loss or anger could inhibit further sense-making. A diagnosis of MS was more difficult to obtain for women respondents, and any sense of certainty that diagnosis provided framed their subsequent sense-making strategies. The complex sequelae of MS require that self-management strategies are both contextual and timely; although even the most accomplished self-managers can lose their sense of self with neurodegeneration. Disease progression can be associated with suicidal ideation, suggesting the need for greater dialogue to ensure that people with MS are adequately supported to fulfil their quality of life at all stages of neurodegeneration. These lay perspectives emphasise the articulation of affect rather than the rendering of a medical diagnosis, although diagnosis may provide a degree of certainty in the short term. The ethos of self-management ensures people attempt to retain their sense of 'normality' and existent social roles for as long as possible, but this ethos can negate both one's ability to self-manage and the management of self.
\end{abstract}


Keywords: diagnosis; Multiple Sclerosis; qualitative; self-management; suicide; symptoms.

\section{Funding}

This research was funded by the MS Society (Grant no. 908).

\section{Acknowledgement}

We thank the men and women who took part in the study and the anonymous reviewers for their advice and comments. 


\section{Background}

Multiple Sclerosis (MS) is a chronic neurological disease which may lead to severe disability (Isaksson et al 2006). In approximately $60 \%$ of people it begins as a relapsing-remitting disease which evolves into a progressive neurological illness (Weinshenker 1994). People generally report subjectively experienced symptoms to their doctor, who diagnose MS on the basis of scientific test results. Symptoms may include deterioration of mobility, vision, sensation, continence and fatigue, all of which may follow an uncertain course. The delay between the appearance of symptoms can take many years and people diagnosed with MS may subsequently live with greatly diminished quality of life (NICE 2014).

\section{Diagnosis}

Diagnosis of MS includes clinical and paraclinical studies which may require 'objective clinical evidence' identified from cerebral spinal fluid and magnetic resonance imaging (McDonald et al 2001). An 'attack' (indicative of exacerbation or relapse) is defined as a patient reported episode of symptoms, lasting more than twenty four hours in the absence of fever or infection (Polman et al 2011). While clinically useful, these signs and symptoms are 'scientifically arbitrary' because of the difficulty of setting a ceiling at which MS exists (Weinshenker 1994). Although life expectancy is unchanged for people with MS, their rate of suicide is seven times that of the general population (Weinshenker 1994).

Early sociological studies of health and illness focused on the salience of diagnosis as category and process infused with social, cultural and historical significance (Blaxter 1978). While Parsons (1958) noted the legitimising function of diagnosis, allowing 'sick' individuals' exceptions from society and access to health services, 
Foucault (1973) and Illich (1976) identified the rendering of diagnosis and associated medical surveillance as potentially disempowering. Stewart et al (1982) employed MS as an example of a chronic condition to critique Parson's notion of the 'sick role' as more suited to theorising acute episodes of illness; while Robinson (1990) used a narrative approach to analyse four hundred and fifty written accounts provided by people who attended a Multiple Sclerosis support group. Robinson (1990) concluded that most respondents provided a 'heroic' or 'courageous' progressive personal narrative, indicative of a particular narrative genre associated with 'living with' and 'overcoming' the physical manifestations of their disease; but also identified a more minor 'tragic' narrative, which became manifest as symptoms increased and people with MS became less able to participate in the world around them.

With progressive MS diagnosis may not be a one off event, rather reframing may occur as symptoms progress or new symptoms replace or magnify those already in existence. While the patient may cast their symptoms within a subjective context, health professionals use an array of 'objective' classification systems for 'doing' diagnosis (Frank 1995). The heterogeneous and shifting nature of neurological symptoms make them particularly difficult to name and control (Nettleton 2006; Locock et al 2009), and a diagnosis of MS can be hard won and subsequently rescinded as symptoms change or fail to meet diagnostic criteria (Nettleton 2006). For Nettleton et al (2004), these neurological narratives are examples of Frank's (1995) chaos narrative (with no clear beginning or ending), rather than Robinson's heroic narrative. If, as Sointu (2015) contends, one's capacity for sense making of health and illness is shaped by the dominance of biomedicine as the primary means of defining and treating ill health, we need to explore the experience and impact of 
the diagnostic process on sense making processes, and subsequent management strategies employed by people with MS.

\section{Self-Management}

Like diagnosis, notions of self-management for MS are complex. In the UK, the NICE guideline for MS (NICE 2014) recommends 'self-management' (NICE 2014b). Exercise regimens are recommended for the management of fatigue and immobility and self-titration of medication is suggested for the management of spasticity but, between reviews by health professionals, people with MS are encouraged to selfmanage (NICE 2014). The MS guidance (NICE 2014) incorporates qualitative studies, but while none define self-management, collectively they describe implicit expectations that patients devise their own mechanisms for "going away and living with it' (e.g. Malcomson et al 2008). More recent qualitative studies have identified a lack of ongoing provision to support self-management (Deibel et al 2013) and shown how people with MS often receive generic rather than tailored information and education (Chaplin et al 2012).

The term 'self-management' has received much critical attention. Formal programmes originated from the Chronic Disease Self-Management Program (CDSMP) developed in the USA in the 1990s and provided groups of patients with a course about their conditions and tasks to utilise fewer health care resources (Lorig et al 1999). Kendall et al (2007) suggest that the CDSM approach to selfmanagement was adopted as a formal policy initiative in the UK to reduce the financial burden of chronic conditions and involve patients in health care delivery (DoH 2000). Three layers of management were enshrined in this policy (DoH,2004): case management for patients with multiple complex conditions, disease 
management supported with packages of incentivised support in primary care, and self-management for low risk patients $(70-80 \%$ of those with chronic conditions) (Kendall et al 2007). However, Kendall et al (2007) also differentiate between formal self-management strategies which refer to the practical steps taken to employ resources and minimise difficulties in everyday life, and a more insidious selfmanagement whereby people try to retain their sense of self in the face of their condition.

In the UK, Bury et al (2005) cautions that evidence for CDSMP based interventions has been overstated, mediating factors have been underexplored, and any long term benefits have yet to be determined; while Townsend et al (2006) suggest that selfmanagement policies and practices need to recognise the burden associated with balancing symptom management along with social roles and activities of daily life. They identify a range of strategies that patients employ to maintain balance, including pacing activities, talking to others, use of medication, use of formal services and informal networks. Self-management has been used variously to denote selfcare in accordance with the knowledge of experts, as the domain of experts, and as a form of emancipation (Kendall et al 2011). However, the normalisation of selfmanagement obscures the hard work involved and the lengths to which patients go to maintain normal daily life; and self-management needs to be supported in ways which acknowledge and accommodate contextual factors which enable patients to meet their own goals, rather than merely managing symptoms (Morden et al 2011; Ong et al 2011; May et al 2014; Ong et al 2014).

The utility of self-management enshrined in the NICE guideline for MS specifically (2014) has been challenged by an international consensus conference which identified a paucity of evidence to support the use of self-management interventions 
in MS, noting that where evidence exists it tends to concern one symptom rather than the many that typify the condition (Fraser et al 2013). Furthermore, despite the introduction of a new quality standard to drive improvement (NICE 2016), MS charities in the UK remain sceptical due to the lack of additional resource provision (Robinson 2016).

MS is more prevalent among women and research has identified how MS is gendered. Explorations of help seeking more generally have identified the lengths that many women go to before their symptoms are legitimated (Werner et al 2003), while studies with men have challenged the stereotype of reluctant care seekers, noting how gender intersects with notions of risk and responsibility (Robertson 2006), health beliefs (O’Brien et al 2007), and occupational category (2011). Payne and Doyal (2012) also contend that recent neoliberal policies have reinforced gender inequalities, such that women's domestic responsibilities have increased, while men have been further disenfranchised from help seeking. With regards to MS, studies have identified how women respond to the spatial and temporal changes that disease progression brings by restructuring their roles and activities (Dyck 1995), strategically avoiding physical exertion, and seeking out supportive social relationships (Schneider et al 2010). In contrast, men experience MS as a form of social loss (Kohler-Reissman 2003), and battle against symptoms such as fatigue, which in turn leads to lower self-efficacy than women (Smith 2015).

The research questions that this paper seeks to answer are:

- Is the on-going process of diagnosis oppressive or empowering?

- Is self-management burdensome or an expression of autonomy?

\section{Methods}


Lay perspectives of people with progressive MS were gathered by purposive sampling (Pope and Mays 1999), including both participants active in the MS community and those in contact with specialist MS services. We gave a presentation about the research at MS Society meetings in two cities in South West England, and provided information to sixteen people with MS who expressed interest in this study. We also enlisted MS Specialist Nurses (MSSNs) to identify people with various stages of MS symptomology and diagnosis using the Expanded Disability Status Scale (EDSS) which quantifies disability and changes over time (Kurtze 1983), and criteria which neurologists use to diagnose MS (McDonald 2001; Polman 2011). The MSSNs identified and gave information packs to ten further people who met the study's inclusion criteria. Fourteen people with progressive MS consented to be interviewed, seven from the MS Society meetings, and seven identified by MSSNs.
A topic guide was developed based upon a review of the existing literature, clinical experience, and input from an advisory group (comprising two senior qualitative researchers with expertise in MS and rehabilitation, a neurologist, and a person with relapsing remitting $\mathrm{MS}$ ). It included demographic information, the broader context of the illness experience, sources of support, and lay perspectives of living with MS. It was piloted with two people with MS, and upon review a decision was made to split the data collection into two separate interviews, to prevent the interviewees from becoming fatigued and for us to tailor the questions in the repeat interview (Dickinson-Swift et al 2008).

Initial interviews were conducted (AA) in participants' homes in 2010 , lasted between thirty and ninety minutes and were digitally recorded. Repeat interviews were conducted with all participants (AA) six months later, and lasted thirty to sixty minutes. Interviews were transcribed verbatim and thematically analysed (AA and 
BB) using iterative readings and summary sheets to record key themes and narratives (Mishler 1996). Their inclusion in an Nvivo managed dataset allowed within-case and across-case analysis (AA, BB and CC) (Holland et al 2006). Our foci were the process of diagnosis and the long-term sequelae of MS and its sociological contexts.

\section{Results}

Fourteen people with primary progressive $(n=9)$, or secondary progressive Multiple Sclerosis $(n=5)$ participated. Ten were women and four were men. The duration of MS ranged from four to fifteen years, and mobility ranged from unaided to wheelchair use. Participants' mobility, their socioeconomic circumstances and age were reflected in their accommodation, with some living independently and others living in assisted or modified social housing. Nine identified walking as their most important symptom, three identified mobility more generally, and the remaining three each identified breathing, pain and depression. [Table 1 here]

\section{The diagnostic process and 'certainty'}

There were gendered differences in the experience of diagnosis. The men did not consider themselves to have symptoms of MS and found the diagnosis difficult to come to come to terms with, whereas the women found it harder to establish a clear diagnosis of MS, or welcomed a diagnosis as a form of validation.

The men interviewed responded to their diagnosis with a mixture of shock and fear. All reported that 'something was wrong', with some undertaking self- diagnosis or retrospectively attributing their diagnosis of MS to longstanding symptoms which 
they had not previously reported to a doctor. Arthur, a businessman, had always experienced poor co-ordination and lacked the co-ordination to run, and experienced a sudden exacerbation of symptoms at the office:

So I've always found it hard work doing things like, l've never been top, a top performer at things like that...I always thought I can't do this, you know, I'll, ah, but until it was diagnosed of course, I mean I died when I was told 'you've got MS.'... (Arthur)

In contrast, Brian, an engineer, had symptoms identified by his wife and did not understand why he was referred to a neurologist. He was shocked by his unconfirmed diagnosis of MS, which he subsequently looked up on the internet:
W: Then you went to the Eye Infirmary... And they referred you to the neurologist.
P: Yeah, and I thought 'why are they doing that?' But anyway, they referred me there and course, they give me the note, I'm sat there waiting and course, 'well, l'll just read' and this, a doctor put down, um...Question mark, possibility, um, MS and I thought to meself, 'what the hell's MS?' Course I looked it up...Frightened myself [laughter], frightened me to death, I thought 'bloody hell'. (Brian)

When Clive, a salesman, began to experience increasing numbness in his leg, it was a family member, also a physician, who referred him to a neurologist. He too found the diagnosis difficult to accept:

[Relative] was a consultant there and one of her sort of friends, who was a neurologist.... he sort of saw me... said, you've got MS, it might never happen or it might do. Lots for my walking I had hundreds of bloody tests, and vision tests and coloured dyes in the eyes and god knows what else...Very difficult. They've made a mistake! (Clive)

Finally, David, a surveyor, had a history of 'fumbling and stumbling' like Arthur, and similar to Clive he questioned the diagnosis of MS, taking years to come to terms with it: 
It's taken me a number of years actually to finally get used to the fact that l've got MS because in the initial days I used to say, are you sure? Are you really sure? (David)

The duration of symptoms before help- seeking in these accounts is indicative of men's general reluctance to help- seek until 'minor symptoms' become more serious (O'Brien et al 2005), overlaid with MS specific symptoms which can lead to perceptions of a failure of both masculinity and medicine.

In contrast, the women interviewed expressed that when they sought a diagnosis they were not believed, or were 'fobbed off' with a psychosomatic reason (Payne et al 2012), with some believing that their diagnosis was withheld. Ivy, an administrator, with pre-existing symptoms for many years, believes that the diagnosis of MS was added to her medical notes without her being informed:

Now when I moved here [GP] came to introduce herself and she said when were you diagnosed? I said 2003, oh no she said I read your notes through; you were actually diagnosed in 1979. But all the specialists then said to me, we know what's wrong with you but we think any treatment might be worse than the actual symptoms, just carry on, so that was it. But l'd fallen from late teens and of course with MS your knees don't bend, you just go flat on your face. (Ivy)

Nancy was a nurse with caring responsibilities for her family, and her diagnosis of MS was rescinded and then subsequently reinstated:

P: That's a joke; my GP told me that I had a mild form of MS, it was called, it was called Uthoff's phenomenon, then I went and saw the Consultant and he told me I didn't have it, and then I saw a different Consultant and he told me I had primary progressive...

I: And then did it take years to get a proper diagnosis or?

P: Probably took about $4 \ldots$ in hindsight... I didn't have a clue, (Nancy)

Similarly, although Hannah, a pharmacist and keen runner, had co-ordination problems for many years, her GP was quick to diagnose her with migraines: 
Yeah I had a club foot. Well you know what it's like with the motion of running, I felt like I was carrying a club foot with... thick shoes, that's how it felt... I went to my doctor, [GP] ... it took about 18 months to diagnose cos they thought it was a migraine. (Hannah)

Joan, an ex-barrister, used a keyboard to provide her account as her symptoms impeded her communication, and suggests that her symptoms continue to be considered as psychosomatic:

I was diagnosed Aug 2002. It was very quick, woke up in middle of July 2002 with sensory symptoms $\mathrm{R}$ side, the sort of thing which could have been nothing but equally you knew would not be unreasonable to take to a GP. Waited 2 weeks, hadn't got better, went to GP (private), referred to neurologist, he sad either a stroke or brain tumour or MS, did tests came back in 2 weeks, MS. Confirmed it with EVP. Just on MRI, no LP.... I find it hard to buy into any psych explanation but am willing to give it a try. I would prefer them to say "we don't understand", rather than "therefore it must be pschy", explanation given that all is electrical/chemical at cellular level anyway. (Joan)

Werner et al (2003) contend that a lack of diagnosis and/or a diagnosis that is deemed 'psychological' conflates symptoms with immaterial and fictitious origins, and renders women's experience invisible.

Two women described the diagnosis, and the perceived certainty that it brought, in terms of relief. Diagnosis can come with an 'affective clout', as a form of validation, which permits the symptoms to be considered 'true' (Sointu 2015). For Edna, a yoga teacher, the certainty of a diagnosis was in sharp relief to the uncertainty of progressive symptoms which had made her question her existence:

[Diagnosis] I, I think almost a relief because l'd just known there was something wrong you see for all those years and almost as soon as l'd had my hip replacement you see, and I thought there is something horribly wrong... I mean at the time l'd sort of said to people 'you know, l'd rather be dead than live like this', you know, I, I really would. (Edna)

Whereas Kate, a businesswoman who had just started her own business when diagnosed, experienced relief because even her own Consultant disbelieved her: 
Kept turning me feet over and falling down...well the diagnosis was a relief because even my Consultant, who wasn't an MS specialist, would imply that I was making things up (Kate)

Where diagnosis was hard one, it became a signifier of control, albeit an illusory and often transient signifier:

I have so often wished that when I saw my neurologist and told him of a development he would plot a point on a graph and say ok, this is how things are going now. Rather like a midwife doing a baby's weight. and I sort of felt that with people saying that the best guide to future is how disease had gone in the past, you really need a good way of measuring how it has gone in the past.... But it must be hard because the patient's baseline is constantly changing. I can't imagine now what it must be like to go out and go shopping for example. (Joan)

Although Joan wanted to know how 'her' MS would progress, she was aware that this was clinically difficult to predict, and progression unpreventable.

There was often an assumption that diagnosis would (finally) facilitate access to resources which would empower respondents and facilitate their independence, but (as detailed below) this was often not the case. Where a diagnosis was not believed or perceived as hidden, this eroded trust and inhibited further help-seeking and sense making activities (Sointu 2015).

\section{Sense making and uncertainty}

Gender differences were also evident in the sense making process. Women employed a range of strategies that enabled them to carry on with important aspects of their lives, while men were more likely to contextualise MS in relation to the loss of valued roles and functions.

Women were more willing to employ a range of positive strategies to assist with sense making, and maintaining their credibility (Werner et al 2003). To enable her to 
continue working, Edna employed both contingency (by getting her students to assist) and disclosure (being honest with clients about what to expect):

There's very little that I can demonstrate anymore but, but my students are so, so fit you know ... l'm keeping everybody else really fit and... if someone rings me and says you know, 'can I start coming to your classes' and I have to say ... 'well, I will tell you that I've actually got MS because you'll notice when I'm walking that I, you know, I'm very sort of crippled but, um, apart from that I'm alright'. (Edna)

Similarly, Kate found that using a wheelchair enabled her to continue working and ensure customer relations:

[If] somebody new came in at the door behind me, turning round was an awful effort and by the time I turned round I was glaring at this new person, so I went to a manual wheelchair quite quickly because it solved that problem... with a little manual wheelchair I was able to whirl round and still have a grin on me face and that seemed to work brilliantly and people would say you know, what are you doing in a wheelchair, and I said oh I've got MS and I never, never hid it. (Kate)

Both women suggest honesty and contingency allow them to continue aspects of their life which are valued. This is echoed by Joan, who similarly views a wheelchair as merely a device for empowerment:

everything books etc all have "wheelchair" as the epitome of serious problems but in fact wheelchair is like wearing glasses I guess lots of things when you get close up you see distinctions which weren't there before so an able bodied person thinks "wheelchair" and views the expression "wheelchair user" as being just PC but in fact difference between "user" and "dependant" and "confined to" which are significant. (Joan)

Many respondents dreaded the increased use of aids, but retrospectively their value in facilitating the maintenance of independence was acknowledged.

In contrast, the men reported or feared being perceived as 'drunk' which Isaksson et al (2006), identified can lead to feelings of shame and lower self-esteem and erodes one's long term ability to manage. Arthur's experience of sensory symptoms, and his 
doctors' perception that he had been drinking alcohol, inhibited his ability to communicate and subsequent confidence:

The doctors thought I were drunk, before I was first diagnosed... I wasn't drunk, which used to annoy me something chronic cos I didn't even drink... me brain knows what it wants to say but me mouth says something a bit odd, in a different way... Well, it was me voice for one thing, which sounded drunk and me memory and, and I thought to meself: it is, well, you know, cos, I'm, I'm a communicator! (Arthur)

Similarly, Brian was accused of being drunk by a client, which resulted in him being investigated by his boss and loss of his professional autonomy:

I said 'so, what, what's going on here?' he said 'well, I'll tell you the truth', he said, he said, 'I can see there's absolutely nothing wrong' he said 'but we've had a phone call when, and they, from, um, the manager of a store or something saying you were drunk.' (Brian)

These men also described a sense of anger about their loss. Like those interviewed by Kohler-Reissman (2003) anger was associated with the decline of their bodies and their social worlds. This immediate impact is recognisable in Clive's response:

Well it frightened the wife off, I was that pissed off with the world... The anger of it [Diagnosis]...I suppose it always shows itself to those closest to you (Clive)

Whereas David described a slower process of loss:

To be honest that is just what it was doing, it was a very slow, gradual process that, you know I found it more and more difficult to do certain things, you know... I can't even stand on a pair of steps to put a lightbulb in or anything like that, I can't do anything practical, nothing at all. (David)

These findings substantiate research which suggests that women's perceptions of their disease state, relative to men, ensures that they are better able to "psychologically buffer" the debilitating aspects of MS (Miller et al 2006). Here, resilience appears to enable self-efficacy, whereas perceived loss of control inhibits adjustment. 


\section{Self-management and Management of self}

Although respondents were asked about formal self-management programmes, they described their own self-management strategies (Townsend et al 2006; Ong et al 2014); suggesting both a lack of awareness of formal strategies for MS (NICE 2014; NICE 2014b) and individualised responses to the heterogeneous nature of symptoms.

Approaches to self-management strategies were symptom specific. Joan, who has cognitive difficulties, uses memories associated with her functional ability to remember specific events temporally and to chart her own disease progression:

I tend to try to identify times etc by whether using stick, or crutches, or manual chair, or manual chair with power wheels, or electric chair. (Joan)

In order to manage fatigue, Edna uses meticulous planning and pacing, either undertaking tasks early in the day or setting the day aside for evening events:

Yeah, it's probably better when I get up in the morning ... When I go to do my grocery shopping I go really early in the morning, at eight o'clock in the morning, which suits me fine and then just sort of leaning on the trolley. (Edna)

Olivia, with multiple symptoms, fostered a 'use it or lose it' mentality, which involves restructuring and reframing temporal space in order to maximise quality of life:

I very much feel that you keep going and you use it otherwise you know if I didn't do it I wouldn't be able to do it. (Olivia)

This 'can do' attitude was particularly evident in accounts where a respondent was also a carer for someone else. Caring was perceived as a form of social participation, a means of demonstrating control, and a way of retaining normalcy, even when their own wellbeing was jeopardised (Townsend et al 2006; Kendall et al 
2007). As both Arthur and Nancy suggest, caring for someone else can also be a device for not worrying about oneself:

I probably would be worse actually [without wife to care for], at least l've got someone to focus on apart from me...I don't worry about meself much anyway. (Arthur)

You've got to get on with it, yeah I look after me mum, I cook her meals and you know sleep over there...first of all I was just a pain, I felt so sorry for myself, why me, why me, it probably took about six or seven years to accept it easily, but now l've got me mobility scooter, you know, I just get on and do what I can. (Nancy)

Both were independently mobile when interviewed, but 'feared' for a time when they or those they cared for might require care beyond their capacity.

In contrast, Clive, who walked with bilateral aids, contested his diagnosis and subsequently lost his marriage and job, was unable to detail his strategies for selfmanagement. Instead he spent time information seeking and was hopeful for a cure:

There might be a cure!... I spent quite a while on the internet... This Italian guy has found what he thinks is a cure, um I think that's all quite promising. ... the year 2015, no more MS, and I thought well no-one's going to make that kind of statement unless they know something. (Clive)

Clive's experience exemplifies earlier findings which identified that when the diagnosis of MS is difficult, sense making is inhibited, and role negotiation (such as the adoption of the sick role and associated rights and responsibilities) is subsequently hindered (Stewart et al 1982).

Women seemed better able to manage the loss of their working identity, and this may be due women already having more flexible strategies for managing the social and private spheres, because of gendered career opportunities, the experience of motherhood and other caring activities:

Because like I say it's a family-run company, and it's only me so I couldn't work in the office opposite the lady who owned the business because that 
would mean l'd need liability insurance to cover me in case I was there in the office on my own ...So it came to a mutual agreement that I should, that I'd leave. (Grace)

Grace seemed resigned to giving up her post because of the uncertainty associated with continued relapses, and her realisation that there were increasingly tasks which she could no longer preform.

Flexible self-management strategies were also required to undertake leisure activities, perceived as essential for maintaining both function and quality of life. For example, Nancy, a very physically active nurse described how she moderated her exercise as her MS has progressed:

I used to do a lot of walking, I used to play squash and badminton and then I couldn't do that cos the foot kept flapping... I bought a really decent exercise bike and actually this leg was really flabby... I do at least an hour a day. (Nancy)

However, with time and disease progression several respondents detailed how they had stopped cherished activities, which were indicative of the failure of selfmanagement more generally:

I used to go swimming with the local swimming classes that were run for sort of disabled people but I had to give that up ... one of the problems I had was that on this bad leg my toes tend to curl under when I walk, you know, and therefore it was very uncomfortable, very painful to go into the water to be able to swim. (David)

Strong supportive social networks have been described as key resources for people self-managing chronic conditions. Ong et al (2014) have cautioned against premising self-care on obligational relations among friends, family and neighbours, and this research has demonstrated social networks diminish for people with progressive MS, as they lose their ability to participate in wider society and thus experience 
cumulative disadvantage (May et al 2014). Exceptional examples were provided by those active in the MS community:

I've just taken on being chairman of the MS places locally...I think one adapts one's life around it. (Clive)

I've actually led a much higher profile life since l've become disabled because I've become pretty much a leader in the disabled community, and one of the first things that happened was that I won a place on the [committee] (Kate)

Both suggested that their charitable roles fostered their self-esteem and a sense of importance and, like those in the MS community interviewed by Robinson (1990), these were the only respondents whose altruism reflected a heroic narrative.

\title{
Fear for the future and death as the only certainty
}

As isolation and dependence increase with neurodegeneration, quality of life decreases. These narratives included heightened emotional responses and suicidal ideation, and a sense was gained that death becomes the only certainty with late stage MS.

Those with prior experience of caring for people with neurodegeneration suggested that this experience increased both their anxieties and fear for the future:

\begin{abstract}
If I be quite honest with you I fear for the future, I fear if anything happens to the husband cos I couldn't manage to live here on my own...I fear for how much worse I could get yes definitely do... each time when I go to the toilet in the night I think to myself how much longer can I manage this, is it going to get worse, I think I frighten myself but you know it's always in the back of your mind... how it's going to end? Because, I mean I've seen people at the worst end. (May)
\end{abstract}

Several respondents had contemplated suicide, and as with other neurological conditions (Nettleton 2004; Locock et al 2009), suicidal ideation was particularly 
prevalent in those who experienced isolation or dependence, although in Ivy's case, disease progression had denied her the means by which to take her life:

Truthfully, if I could get to Zurich I would be there because my mother was 94 when she died, if I take after her I can't spend that long just sat in a chair.... Oh I don't dwell on it, I say it funnily but I'm really snookered, I've no bath so I can't drown myself, I'm allergic to Ibuprofen, paracetamol and aspirin so no way would I overdose in case it went wrong cos I know what the symptoms are when it does go wrong, I can't walk down to the sea to drown myself [laughter] so l'm just snookered there. (Ivy)

Good days were noteworthy amidst a growing sense that their ability to manage and subsequent quality of life were diminishing:

I know I should be saying what I can do, that's the positive side of things, I should be saying I can still do this, I can still do that, but there's not a lot of things that I still can do that I used to do...Because that's the way I always were before [MS] and I'm not like that now, so. It's like it's gone (Grace)

Wollin et al (2006) found that in the absence of a cure, and as with other chronic conditions requiring palliative care, people with MS can require support as their physical, emotional and spiritual needs increase. More recently Methley et al (2016) identified reluctance among both people with MS and their designated health professionals to label mental health difficulties as pathological, in some cases seeing low mood as part of the normal disease process. Furthermore, their recommendation that the familiarity associated with continuity of care fosters psychological security is at odds with the self-management ethos that fails to acknowledge the diminution of one's capacity to manage over time:

I get so emotional it drives me nuts... even when I don't feel upset I find myself blubbing. (Olivia)

For those men identified as having a persistent sense of anger, their enduring emotional burden further undermined their ability to 'help themselves': 
I think for years and years I've always given to NSPCC and, um, I thought I'll get a little bit more into that. And then they sent me some stuff and that, and they sent me - and I think I can't be doing this, this is too upsetting, you know, the...And then, not, they don't tell you specific but they tell you a specific story of, not you know, you think oh, bloody hell and I'm thinking...I feel like I could kill someone. (Brian)

Even for those women who had previously described their own efficacious selfmanagement strategies, their loss of independence negated future planning and now reduced them to living in the present:

One step at a time I think. There is an element of dread that it will go, it will progress further and there have been one or two signs that my hands aren't as strong as they were. (Kate)

Ultimately, the 'dull inevitability' of neurodegeneration erodes resilience and ultimately leads to the loss of hope:

I have got to the stage when I rather want it to get on with it and finish me off ... Now I am just tired... In a bored sort of way. Yes, I don't feel depressed as such, but it is the sort of dull inevitability of it. And I am quite uncomfortable most of the time. Hate that word, but with the breathing, imagine you can hold your breath for $1 \mathrm{~min}$, and think how you would feel after $50 \mathrm{sec}$. That is how it feels. I want to be able to take a rest from breathing, but of course body won't let you do that. (Joan)

These findings indicate self-management is ultimately burdensome, suggesting that strategic approaches to MS must be both supportive (of psychosocial and physical wellbeing) and supported (resourced by health professionals and access to aids and services) in the long term, and appropriately tailored to individual needs.

\section{Discussion}

We identified a clear gendered response to the experience of living with MS; which suggests that men and women may have different needs, both at the time of diagnosis and during subsequent sense making. However, gender differences tend to diminish with disease progression, as both men and women express fears for the 
future and express suicidal ideation. Such fears can be compounded by additional caring responsibilities, while active participation in the MS community can provide a supplementary source of support.

While earlier research described processes through which medical diagnosis of MS was 'disclosed' (Robinson 1990), our analysis has identified how people selfdiagnose or refute an MS diagnosis. Some were surprised when they were diagnosed with MS, but more gave accounts of incoherent diagnoses, suggesting that poor communication and medical uncertainty add to the perception of fear and ambiguity, rather than the diagnosis per se (de Seze 2012). Others expressed disbelief or fear, suggesting that health professionals need to explore an individual's experiential knowledge and lay interpretations, in order to better support them (Lowden et al 2014). While male respondents expressed surprise at their diagnosis, women often expressed relief. Diagnosis acts as a (albeit transient) explanatory framework (Sointu 2015) which legitimates access to medical treatment and expertise (Nettleton et al 2006) but may not necessarily change the experience of the disease.

These respondents did not frame their experience in relation to state-sponsored selfmanagement programmes, because they were either unavailable or deemed unhelpful (Deibel 2013). Instead they detailed a range of personally developed coping mechanisms and individually tailored self-management practices. Whereas Robinson (1990) identified a dominant heroic narrative, our wider sampling frame provided accounts more akin to Robinson's notion of a tragic narrative, in that for many disease progression was associated with suicidal ideation; or (after Frank) Nettleton's more recent chaos narrative (2004) in that the uncertain path of progression inhibited planning, as previously successful strategies were surpassed. 
These findings suggest the need for disease specific self-management strategies which are tailored to the individual needs of patients within their social contexts (Morden et al 2011; May et al 2014; Ong et al 2014). Less palatable for policy makers and providers could be the suggestion that, in the absence of appropriate self-management strategies, some people with MS might want or need disease management or case management approaches (DoH 2004), which are more resource intensive approaches to the management of long term conditions (Bury et al 2005).

A significant finding of this research is that many respondents have contemplated suicide. Locock (2009) found that people diagnosed with motor neurone disease, a rapidly progressing neurological condition, typically described it as a 'death sentence' (biographical abruption) from which some at least sought to salvage the semblance of self (biographical repair). In this research, some people with MS appeared to describe this process in reverse, such that diagnosis acted as a (temporary) form of narrative repair, which overtime was replaced by abruption or a burgeoning awareness of gradual decline. One fifth of English people who kill themselves have a chronic illness (Bazalgette 2011), and it is imperative that selfmanagement of MS is a meaningful choice for people and adjunct to, rather than instead of, high quality medical treatment and social support (Methley et al 2016).

As the loss of a sense of self is eroded with disease progression, so is an individual's ability to manage (Townsend et al 2006; Lowden et al 2014). Respondents described employing techniques for maintaining both normalcy and independence for as long as possible (McLaughlin et al 1993). However, dwindling self-management could contribute to isolation and uncertainty in the long term and ultimately 'diminish returns' for the required effort (May et al 2014). Self-management should be one of a 
range of strategies for people with MS (Chaplin 2012), and a more individualised approach would view self-management not as a stable category, but as something which diminished over time, and we propose the adoption of a more mutable concept of self-management.

Like Kohler- Reissman (2003) we found that men's stories are infused with the experience of loss which compounds their experience of symptoms (Smith et al 2015), and may inhibit their ability to achieve their own goals which erodes selfefficacy. An initial response to diagnosis of disbelief or anger can hinder subsequent abilities to problem solve and undertake flexible strategies of self-management, and a lack of self-efficacy and resilience, resulting from diagnosis of MS, can be associated with increased depressive symptoms in the long term (Tan-Kristano et al 2015). However, unlike studies that have identified variation in men's accounts of help- seeking generally - along lines of sexuality (Robertson 2006), younger age (O'Brien et al 2005), and high economic status (Farrimond 2011) - we did not identify a reconstituted masculinity. This may be due to the men interviewed all being middle aged (53-66), semi-professional, living in a semi-rural environment; with all identifying the loss of their role as breadwinner as a significant milestone (O'Brien et al 2005). Thus, while our sample reflected the prevalence of MS (two to three times more prevent among women- Fraser et al 2013), future research with a wider sample of men may elicit a more nuanced response and better enable the tailoring of provision. In contrast, women typically described a diversity of responses that better equipped them to develop malleable self-management strategies which were responsive to both symptoms and roles. As with other studies of help-seeking (Werner et al 2003) and those with neurological symptoms specifically (Nettleton (2006), the women interviewed described the 'hard work' involved in having their 
symptoms confirmed. However, we did not find that women drew on friends and relatives for support (Schneider et al 2010), and an important finding from our study is that the progressive nature of MS diminishes social relationships for both men and women, to the extent that an important resource for self-care, assumed to underlie current policies for self-management, may diminish over time and with disease progression (Ong et al 2014). Only the two respondents (Clive and Kate) who identified themselves as active in the MS community were able to draw on this network as a positive resource. In contrast, those with caring responsibilities (Arthur and Nancy) feared for the future and ever diminishing support.

We have identified how people give meaning to the 'dull inevitability' of living with progressive neuro-degeneration. Some respondents described their earliest symptoms with remarkable clarity, whilst others were less clear as to when their MS 'started'. This could be mediated by both their willingness and ability to accept its degenerating nature, as well as other chronic illnesses. Some were clearly struggling to live with a condition which erodes their ability to undertake once taken for granted tasks and activities. By virtue of the heterogeneity of symptoms and experience, these findings may have relevance for people experiencing other progressive conditions. However, this sample were all white British, living in South West England, where people from minority ethnic backgrounds are under-represented (ONS 2011); therefore our findings cannot be generalised to people from minority ethnic backgrounds.

Prospective research is now required to explain how lay perspectives reconfigure as people with MS move from diagnosis through to disease progression; and explore how changing resilience and vulnerability might impact upon one's ability to selfmonitor and effectively self-manage their condition (May et al 2014; Sointu 2015). 
Decades after the identification of the varied life trajectories and illness experiences of people with MS, there remains a need for more assistance to be given to people who are coming to terms with a diagnosis of MS and living with its progressive impact (NICE 2016). For some people with MS diagnosis is empowering in the short term but, in the absence of tailored formal self-management programmes of support, individually identified coping strategies become burdensome over time. We therefore call for greater public discussion of what it is like to live with a progressive and degenerative condition so that both health services and lay support might adequately address the needs of people with Progressive MS and assist them to achieve quality of life where possible.

\section{References}

Bazalgette L, Bradley W, Ousbey J (2011) The Truth About Suicide. Demos.

Blaxter M (1978) Diagnosis as category and process: The case of alcoholism. Social Science and Medicine. 12. 9-17.

Bury M, Newbould J, Taylor D (2005) A rapid review of the current state of knowledge regarding lay-led self-management of chronic illness. London: National Institute for Health and Clinical Excellence.

Chaplin H, Hazan J, Wilson P (2012) self-management for people with long-term neurological conditions. British Journal of Community Nursing. 17. 6. 250-257.

De Seze J, Borgel F, Brudon F (2012) Patient perceptions of multiple sclerosis and its treatment. Patient Preference and Adherence. 6. 263-273.

Deibel F, Edwards M, Edwards A (2013) Patients', carers' and providers' experiences and requirements for support in self-management of multiple sclerosis: a qualitative study. European Journal for Person Centred Healthcare. 1.2. 457-467.

Department of Health (2000) The NHS Plan. London, Stationery Office.

Department of Health (2004) The NHS Improvement Plan: Putting people at the heart of public services. London, Stationery Office. 
Dickinson-Swift V, James E, Liamputtong $\mathrm{P}$ (2008) Undertaking sensitive research in health and the social sciences: Managing boundaries, emotions and risks. Cambridge: Cambridge University Press.

Dyck I (1995) Hidden geographies: The changing lifeworlds of women with multiple sclerosis. Social Science and Medicine. 40. 3. 307-320.

Evans J, Oliffe J, Gregory D (2011) Health, Illness, men and Masculinity (HIMM): A theoretical framework for understanding men and their health. Journal of Men's Health. 8. 1. 7-15.

Farrimond H (2011) Beyond the caveman: Rethinking masculinity in relation to men's help seeking. Health. 16. 2. 208- 225.

Foucault M (1973) Birth of the Clinic: An Archaeology of Medical Perception. New York: Pantheon Books.

Frank A (1995) The Wounded Storyteller: Body, Illness, and Ethics. London: University of Chicago Press.

Fraser R, Ehde D, Amtmann D, Verrall A, Johnson K, Johnson E, Kraft G (2013) Self-Management for People with Multiple Sclerosis: Report from the First International Consensus Conference, November 15, 2010. International Journal of MS Care.15. 99-106.

Holland J, Thomson R, Henderson S (2006) Qualitative Longitudinal Research: A Discussion Paper. Families \& Social Capital ESRC Research Group Working Paper No. 21. London: London South Bank University.

Illich I (1976) The Limits of Medicine - Medical Nemesis: The Expropriation of Health. Middlesex: Penguin.

Isaksson A-K, Ahlstrom G (2006) From symptoms to diagnosis: Illness experiences of multiple sclerosis patients. Journal of Neuroscience Nursing. 38. 4. 229-237.

Kendall E, Ehrlich C, Sunderland N, Meunchberger H, Rushton C (2011) Selfmanaging versus self-management: reinvigorating the coio-political dimensions of self-management. Chronic IIIness. 7. 87-98.

Kendall E, Rogers A (2007) Extinguishing the social?: state sponsored self-care policy and the Chronic Disease Self-management Programme. Disability and Society. 22. 2. 129-143.

Kohler-Reissman C (2003) Performing identities in illness narrative: masculinity and multiple sclerosis. Qualitative Research. 3. 1. 5-33. 
Kuhlmann E, Annandale E (2012) Bringing gender to the heart of health policy, practice and research. In: Kuhlmann E, Annandale E(eds) The Palgrave Handbook of Gender and Healthcare. 2nd edition. Basingstoke: Palgrave Macmillan

Kurtzke JF (1983). Rating neurologic impairment in multiple sclerosis: an expanded disability status scale (EDSS). Neurology. 33 (11): 1444-52.

Locock L, Ziebland S, Dumelow C (2009) Biographical disruption, abruption and repair in the context of Motor Neurone Disease. Sociology of Health and IIIness. 31.7.1043-1058.

Lorig K, Sobel D, Stewart A (1999) Evidence suggesting that a chronic disease selfmanagement program can improve health status while reducing hospitalization, a randomized trial. Medical Care. 37.1.5-14.

Lowden D, Lee V, Ritchie J (2014) Redefining self: Patient's decision making about treatment for multiple sclerosis. Journal of Neuroscience Nursing. 46. 4. E14- 24.

Malcomson KS, Lowe-Strong AS, Dunwoody L. (2008) What can we learn from the personal insights of individuals living and coping with Multiple Sclerosis? Disability and Rehabilitation. 30. 9. 662-674

May C, Eton D, Boehmer K, Gallacher K, Hunt K, MacDonald S, Mair F, May C, Montori V, Richardson A, Rogers A, Shippe N (2014) Rethinking the patient: Burden of Treatment Theory. BMC Health Services Research.14. 281.

McDonald WI, Compston A, Edan G, et al. (2001) Recommended diagnostic criteria for multiple sclerosis: guidelines from the International Panel on the Diagnosis of Multiple Sclerosis. Annals of Neurology. 50: 121-127.

McLaughlin J, Zeeberg I (1993) Self-care and multiple sclerosis: A view from two cultures. Social Science and Medicine.37. 3. 315-329.

Methley A, Campbell S, Cheraghi-Sohi S,Chew-Graham C (2016) 'Meeting the mental health needs of people with multiple sclerosis: a qualitative study of patients and professionals' Disability and Rehabilitation.

DOI: 10.1080/09638288.2016.1180547

Miller A, Dishon S (2006) Health-related quality of life in multiple sclerosis: The impact of disability, gender and employment status. Quality of Life Research. 15. 259-271.

Mishler E (1996) Research Interviewing: Context and Narrative. Cambridge, MA: Harvard University Press.

Morden A, Jinks C, Ong B (2011) Lay models of self-management: how do people manage knee osteoarthritis in context? Chronic IIIness. 7. 3. 185- 200. 
National Institute for Health and Care Excellence (2014) Management of multiple sclerosis in primary and secondary care. Clinical guideline 186. https://www.nice.org.uk/guidance/cg186 accessed 26.02.15

National Institute for Health and Care Excellence (2014b) Patient experience in adult NHS services: Evidence Update February 2014. A summary of selected new evidence relevant to NICE. Clinical guideline 138.

https://www.nice.org.uk/guidance/cg138 accessed 26.02.15

National Institute for Health and Care Excellence (2016) Multiple Sclerosis Quality Standard. https://www.nice.org.uk/guidance/qs108/chapter/list-of-quality-statements. Accessed 05.07.16.

Nettleton S, O'Malley L, Duffey P (2004) Enigmatic Illness: Narratives of patients who live with medically unexplained symptoms. Social Theory and Health. 2. 47-66.

Nettleton S (2006) 'I just want permission to be ill': Towards a sociology of medically unexplained symptoms. Social Science and Medicine. 62. 1167-1178.

O'Brien R, Hunt K, Hart G (2005) 'It's caveman stuff' but that is to a certain extent how guys still operate': men's accounts of masculinity and help seeking. Social Science and Medicine. 61. 503-516.

Office of National Statistics (2011) Population Estimates by Ethnic Group (experimental), Mid-2009. http://www.ons.gov.uk/ons/publications/re-referencetables.html?edition=tcm\%3A77-50029 accessed 26.02.15.

Ong B, Richardson J, Porter T, Grime J (2014) Exploring the relationship between multi-morbidity, resilience and social connectedness across the lifecourse. Health. 18.3. 302-18.

Ong B, Rogers A, Kennedy A, Bower P, Sanders T, Morden A, Cheraghi-Sohi S, Richardson J, Stevenson F (2014) Behaviour change and social blinkers? The role of sociology in trails of self-management behaviour in chronic conditions. Sociology of Health and IIIness. 36. 2. 226-238.

Payne S, Doyal L (2012) Revisiting gender justice in health and healthcare. In: Kuhlmann E, Annandale E(eds) The Palgrave Handbook of Gender and Healthcare. 2nd edition. Basingstoke: Palgrave Macmillan

Parsons T (1958) Definitions of health and illness in the light of American values and social structure. In: Jaco E (ed.) Patients, Physicians and IIIness: Behavioural Science and Medicine. Glencoe, IL: The Free Press.

Polman $\mathrm{CH}$, et al (2011) Diagnostic criteria for multiple sclerosis: 2010 Revisions to the McDonald criteria. Annals of Neurology. 69. 292-302. 
Pope C, Mays N (1999) Qualitative Research in Health Care. London: British Medical Journal Books.

Rinon A, Buch M, Holley D, Verdun E (2011) The MS Choices Survey: findings of a study assessing physician and patient perspectives on living with and managing multiple sclerosis. Patient Preferences and Adherence. 5. 629-643.

Robertson S (2006) 'Not living life in too much of an excess': lay men understanding health and wellbeing. Health. 10. 2.175-189.

Robinson I (1990) Personal narratives, social careers and medical courses:

Analysing life trajectories in autobiographies of people with multiple sclerosis. Social Science and Medicine. 30.11. 1173-1186.

Robinson A (2016) Will NICE's quality standard for multiple sclerosis improve care? Prescriber. 24.05.16

Schneider M, Young N (2010) 'So this is my new life': A qualitative examination of women living with multiple sclerosis and the coping strategies they use when accessing physical activity. Disability Studies Quarterly. 30. 3/4.

Smith C, Fitzgerald H, Whitehead L (2015) How fatigue influences exercise participation in men with multiple sclerosis. Qualitative Health Research. 25.2.179188.

Sointu, E. (2015), Discourse, affect and affliction. The Sociological Review. doi: 10.1111/1467-954X.12334

Somerset M, Campbell R, Sharp D, Peters T (2001) What do people with MS want and expect from health-care services? Health Expectations. 4. 29-37.

Stewart D, Sullivan T (1982) Illness behaviour and the sick role: The case of Multiple Sclerosis. Social Science and Medicine. 16. 1397-1404.

Tan-Kristano S, Kiropoulos L (2015) Resilience, self-efficacy, coping styles and depressive and anxiety symptoms in those newly diagnosed with multiple sclerosis. Psychology, Health and Medicine. 20.6. 635-645.

Townsend A, Wyke S, Hunt K (2006) Self-managing and managing self: practical and moral dilemmas in accounts of living with chronic illness. Chronic illness.2. 185194.

Weisenshenker B (1994) Natural history of multiple sclerosis. Annals of Neurology. 36. S6-S11.

Werner A, Malterud K (2003) It is hard work behaving as a credible patient: encounters between women with chronic pain and their doctors. Social Science and Medicine. 57. 409-1419. 
Wollin J, Yates P, Kritjanson L (2006) Supportive and palliative care needs identified by multiple sclerosis patients and their families. International Journal of Palliative Nursing. 12.1. 
Table 1: Participants experience of Multiple Sclerosis and demographic data

\begin{tabular}{|c|c|c|c|c|c|c|c|c|c|c|c|c|}
\hline Participant & $\begin{array}{l}\text { Type of } \\
\text { MS }\end{array}$ & $\begin{array}{l}\text { Duration } \\
\text { (years) }\end{array}$ & $\begin{array}{l}\text { Primary } \\
\text { symptom }\end{array}$ & $\begin{array}{l}\text { Secondary } \\
\text { symptoms }\end{array}$ & $\begin{array}{l}\text { Disability } \\
\text { levels }\end{array}$ & Age & Gender & $\begin{array}{l}\text { Occupation } \\
\text { /Retired }\end{array}$ & $\begin{array}{l}\text { Housing } \\
\text { Owner } \\
\text { Occupied/ } \\
\text { Rented }\end{array}$ & $\begin{array}{l}\text { Relation } \\
\text { ship } \\
\text { status }\end{array}$ & $\begin{array}{l}\text { Carer } \\
\text { F/T } \\
\text { P/T } \\
\text { LA (Local } \\
\text { authority) }\end{array}$ & Dependents \\
\hline Edna & Primary & 4 & Walking & $\mathrm{N} / \mathrm{A}$ & $\begin{array}{l}\text { Unilateral } \\
\text { aid }\end{array}$ & 66 & Female & Yoga teacher & Owner & Widow & $\mathrm{P} / \mathrm{T}$ & $\begin{array}{l}\text { None -2 } \\
\text { adult } \\
\text { children }\end{array}$ \\
\hline Arthur & Secondary & 13 & Pain & $\begin{array}{l}\text { Falls, speech, } \\
\text { memory, } \\
\text { pains in legs } \\
\text { and chest }\end{array}$ & Furniture & 67 & Male & $\begin{array}{l}\text { Retired- } \\
\text { Senior } \\
\text { manager }\end{array}$ & Owner & Married & $\mathrm{F} / \mathrm{T}$ (wife) & $\begin{array}{l}1 \text { - and } 1 \\
\text { adult child }\end{array}$ \\
\hline Brian & Secondary & 10 & Walking & $\begin{array}{l}\text { Vision, pain } \\
\text { in back, } \\
\text { speech, } \\
\text { balance, } \\
\text { fatigue }\end{array}$ & $\begin{array}{l}\text { Unilateral } \\
\text { aid }\end{array}$ & 54 & Male & $\begin{array}{l}\text { Retired - } \\
\text { Refrigeration } \\
\text { engineer }\end{array}$ & Rented & Married & $\mathrm{P} / \mathrm{T}(\mathrm{LA})$ & $\begin{array}{l}\text { None - } 2 \\
\text { adult } \\
\text { children }\end{array}$ \\
\hline Grace & Secondary & 7 & Depression & $\begin{array}{l}\text { Tingling } \\
\text { hands, } \\
\text { memory, } \\
\text { walking, } \\
\text { incontinence }\end{array}$ & Independent & 53 & Female & $\begin{array}{l}\text { Retired - } \\
\text { administrator }\end{array}$ & Owner & Married & $\begin{array}{l}\mathrm{F} / \mathrm{T} \\
\text { (Husband } \\
\text { and } \\
\text { daughter) }\end{array}$ & $\begin{array}{l}\text { None }-1 \\
\text { adult child }\end{array}$ \\
\hline Clive & Secondary & 15 & Walking & $\begin{array}{l}\text { Tingling } \\
\text { hands, } \\
\text { numbness, } \\
\text { balance }\end{array}$ & Bilateral & 53 & Male & $\begin{array}{l}\text { Technician } \\
\mathrm{P} / \mathrm{T}\end{array}$ & Rented & single & $\mathrm{P} / \mathrm{T}(\mathrm{LA})$ & None \\
\hline Hannah & Secondary & 11 & Walking & $\begin{array}{l}\text { Drop foot, } \\
\text { heavy leg }\end{array}$ & Independent & 53 & Female & $\begin{array}{l}\text { Retired - } \\
\text { factory } \\
\text { worker }\end{array}$ & Rented & $\begin{array}{l}\mathrm{L} / \mathrm{T} \\
\text { Partner }\end{array}$ & $\begin{array}{l}\text { Family } \\
\text { and } \\
\text { friends }\end{array}$ & $\begin{array}{l}\text { None - } 3 \\
\text { adult } \\
\text { children }\end{array}$ \\
\hline Ivy & Primary & 16 & Walking & $\begin{array}{l}\text { Balance, } \\
\text { incontinence }\end{array}$ & $\begin{array}{l}\text { No mobility } \\
\text { at all }\end{array}$ & 66 & Female & $\begin{array}{l}\text { Retired - } \\
\text { administrator }\end{array}$ & Owner & Widow & $\mathrm{F} / \mathrm{T}(\mathrm{LA})$ & $\begin{array}{l}\text { None }-3 \\
\text { adult } \\
\text { children }\end{array}$ \\
\hline Joan & Primary & 11 & Breathing & $\begin{array}{l}\text { Speech, } \\
\text { facial }\end{array}$ & Wheelchair & 40 & Female & $\begin{array}{l}\text { Retired - } \\
\text { lawyer }\end{array}$ & Owner & single & $\mathrm{F} / \mathrm{T}(\mathrm{LA})$ & None \\
\hline
\end{tabular}




\begin{tabular}{|c|c|c|c|c|c|c|c|c|c|c|c|c|}
\hline & & & & $\begin{array}{l}\text { expressions, } \\
\text { non-weight } \\
\text { bearing }\end{array}$ & & & & & & & & \\
\hline Kate & Primary & 11 & Walking & $\begin{array}{l}\text { Incontinence, } \\
\text { non-weight } \\
\text { bearing }\end{array}$ & Wheelchair & 73 & Female & Retired - IT & Owner & Divorced & $\begin{array}{l}\mathrm{P} / \mathrm{T} \\
\text { (daughter) }\end{array}$ & $\begin{array}{l}\text { None- } \\
\text { adult } \\
\text { daughter }\end{array}$ \\
\hline Louise & Primary & 7 & Walking & $\begin{array}{l}\text { Numbness in } \\
\text { hand and } \\
\text { arm }\end{array}$ & Independent & 66 & Female & $\begin{array}{l}\text { Retired - } \\
\text { Teacher and } \\
\text { IT }\end{array}$ & Owner & Single & None & None \\
\hline May & Primary & 10 & Mobility & Swallowing & Furniture & 53 & Female & $\begin{array}{l}\text { Retired - } \\
\text { catering }\end{array}$ & Owner & Married & $\begin{array}{l}\mathrm{F} / \mathrm{T} \\
\text { (husband) }\end{array}$ & $\begin{array}{l}\text { None }-3 \\
\text { adult } \\
\text { children }\end{array}$ \\
\hline Nancy & Primary & 10 & Mobility & N/A & Independent & 53 & Female & $\begin{array}{l}\text { Retired - } \\
\text { Nurse }\end{array}$ & Owner & Married & $\begin{array}{l}\mathrm{F} / \mathrm{T} \\
\text { (husband) }\end{array}$ & $\begin{array}{l}\text { None - } 1 \\
\text { adult }\end{array}$ \\
\hline David & Primary & 11 & Walking & $\begin{array}{l}\text { Balance, co- } \\
\text { ordination, } \\
\text { pain in back, } \\
\text { numbness }\end{array}$ & Independent & 66 & Male & $\begin{array}{l}\text { Retired-civil } \\
\text { servant }\end{array}$ & Owner & Married & $\mathrm{P} / \mathrm{T}$ (wife) & $\begin{array}{l}\text { None - } 1 \\
\text { adult }\end{array}$ \\
\hline Olivia & Primary & 9 & Walking & $\begin{array}{l}\text { Neuritis, } \\
\text { numbness, } \\
\text { balance }\end{array}$ & Independent & 67 & Female & $\begin{array}{l}\text { Retired - Pub } \\
\text { owner }\end{array}$ & Owner & Married & $\begin{array}{l}\text { F/T } \\
\text { (Husband) }\end{array}$ & $\begin{array}{l}\text { None }-1 \\
\text { adult and } 1 \\
\text { adult } \\
\text { deceased }\end{array}$ \\
\hline
\end{tabular}

